\title{
Targets to tackle the obesity epidemic: a review of twelve developed countries
}

\author{
lain K Crombie ${ }^{1, *}$, Linda Irvine ${ }^{1}$, Lawrence Elliott ${ }^{2}$ and Hilary Wallace ${ }^{1}$ \\ ${ }^{1}$ Department of Public Health, Division of Community Health Sciences, University of Dundee, Mackenzie \\ Building, Kirsty Semple Way, Dundee DD2 4BF, UK: ${ }^{2}$ The School of Community Health, Napier University, \\ Edinburgh, UK
}

Submitted 29 January 2007: Accepted 6 March 2008: First published online 22 April 2008

\begin{abstract}
Objective: Health targets describe government intentions for improving population health. The present paper determines whether the targets which twelve developed countries have set for obesity match the seriousness of the public health problem.

Design: Policy documents on general public health, obesity, nutrition and physical activity were obtained by repeated searches of government websites. Details of all relevant targets on overweight, obesity, nutrition and physical activity were extracted.

Results: Only four of the countries studied have set targets for specific reductions in the prevalence of obesity. Two have targets that only mention reducing the prevalence of obesity and two other countries wish to halt the rise in prevalence. Two countries currently have targets which are much less ambitious than those in previous policies. No obesity targets are stated in the policies of four countries. Many of the countries studied have set detailed nutrition targets, but these seldom identify desired changes in dietary behaviour. No country has set targets for a reduction in energy intake. The physical activity targets reflect recommendations from the 1990s. Few targets are set for health knowledge or behavioural intentions which are prerequisites for desired lifestyle changes.

Conclusions: Most of the countries studied have either set no targets or set very modest targets for reducing the prevalence of obesity. Many countries have physical activity targets that are likely to be insufficient to prevent obesity. Governments need to reconsider targets on obesity and to develop shorter-term targets which monitor desired lifestyle changes.
\end{abstract}

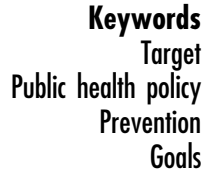

Tackling obesity should be a priority in the public health policies of developed countries ${ }^{(1,2)}$. One way to assess this is to examine the targets that are set for reducing the prevalence of obesity. The use of targets in health is said to have been inspired by the 'management by objective' approach used in the business world ${ }^{(3)}$. The USA pioneered the setting of health targets in $1979^{(4)}$, but targets became a common feature of public health strategies following the launch of the WHO's Health For All initiative ${ }^{(5)}$. The European Regional Office of WHO set thirty-eight targets in $1984^{(6)}$. Not everyone immediately welcomed setting targets $^{(7)}$, and one health minister even described them as political suicide ${ }^{(8)}$. The importance of health targets was reasserted in the WHO's renewed initiative Health For All in the 21st Century ${ }^{(9)}$, for which the European Region set twenty-one targets.

Targets have been described as the first step towards the achievement of health ${ }^{(10)}$, as a means to give policy focus and recognizability ${ }^{(11)}$ and as a way to keep health policy on course ${ }^{(8)}$. Targets can be classified into three groups ${ }^{(12,13)}$. Inspirational targets, often called 'goals' or 'objectives', are intended to stimulate policy development and action at national and state levels. Managerial targets are set to assist the development of detailed plans for the implementation of policy. Finally, technical targets enable the measurement of progress towards achievement of the overall goals. Targets often set the desired amount of improvement and the date by which this should be achieved $^{(6,12,13)}$. The use of targets demonstrates a commitment to achieve improvements within a specified time period and to monitor progress towards goals. Thus, the setting of health targets may be taken as a proxy for governments' commitment to tackling specific health problems.

The present study reviews goals and targets for overweight and obesity in twelve developed countries. 
Because they are directly relevant to obesity, targets for nutrition and physical activity are also reviewed.

\section{Methods}

Policy documents which address obesity were obtained from twelve developed countries from three continents: Australia, Canada, Denmark, England, Ireland, Japan, New Zealand, Northern Ireland, Scotland, Sweden, USA and Wales. Government websites were searched using key terms: public health policy; overweight; obesity; physical activity; and nutrition. Independent searches were carried out with an Internet search engine using key terms of country name and policy, with each of the following topics: public health; obesity; overweight; nutrition; and physical activity. The reference lists of the documents obtained were then reviewed to identify further documents. These searches were repeated until the policy and background documents were obtained for all countries. Policy documents published up to January $2008^{(14-42)}$ were reviewed by two independent observers (L.I. and I.K.C.), and details of all relevant goals and targets on overweight, obesity, nutrition and physical activity were extracted.

The terminology used in public health policies varies between countries and over time. The USA uses the term 'objectives' to describe its numerical targets ${ }^{(14)}$. Denmark sets overall objectives and intermediate aims and identifies specific target groups within the population ${ }^{(15)}$. Northern Ireland used the term 'targets' in its 2002 public health policy ${ }^{(16)}$, then replaced it with 'health outcomes' in the 2004 version $^{(17)}$. To ensure that all statements of commitment to tackle obesity were obtained, the present paper uses the term 'target' to mean the intended improvement in a specific health outcome, irrespective of the label attached to it in the policy document. The operational definition we have used does not require that the amount of health gain or the date for achievement is specified, again to ensure complete ascertainment. This definition is less strict than has been used elsewhere ${ }^{(12)}$, but it enables us to identify whether or not public health policies express the desire to tackle the burgeoning obesity epidemic.

Targets for nutrition cover a wide range of topics including some which are directly relevant to obesity, such as fat and sugar intake, and others which are less relevant such as $\mathrm{Na}, \mathrm{Ca}$ and oily fish intake and Fe deficiency in pregnant women. For reasons of relevance and brevity we have focused on targets most relevant to obesity: the consumption of fat, sugar, grain, bread and cereals, and fruit and vegetables.

\section{Results}

\section{Targets for obesity}

Eight of the countries studied have set targets for obesity, either in general public health policies or in stand-alone obesity policies (Table 1). There are marked differences between these countries in the initial prevalence of obesity, the amount of desired improvement and the date by which this should be achieved. The USA ${ }^{(14)}$ sets the most ambitious targets. These are to increase the proportion of adults who are at normal weight and to reduce the proportion of adults and children who are obese. It first set targets for overweight in $1990^{(18)}$, but did not set obesity targets until $2000^{(14)}$. Japan ${ }^{(19)}$ is the only other country to specify the desired reduction in the prevalence of obesity among adults (note that obesity is defined as BMI $>25$ $\mathrm{kg} / \mathrm{m}^{2}$ in Japan, whereas it is defined as BMI $>30 \mathrm{~kg} / \mathrm{m}^{2}$ in all other countries). The current New Zealand target is to reduce the prevalence of obesity without specifying when or by how much ${ }^{(20)}$. The previous target set in 1993, and restated in 1997, was to prevent an increase beyond $10 \%$ in men and $13 \%$ in women ${ }^{(21)}$. However by 2003 the prevalence of obesity had risen to $20 \%$ for men and $22 \%$ for women. Australia intends to reverse the rise in children by $2008^{(22)}$, but does not specify the amount of reduction to be achieved. A target to halt the rise in obesity among Australian adults by 2007 was set in a 1997 document, but this was rescinded in September $2006^{(23)}$. No new targets have been set. Northern Ireland ${ }^{(16,17)}$, Denmark $^{(24,25)}$ and Sweden ${ }^{(26)}$ wish only to halt the increase in the prevalence of obesity among adults. Northern Ireland ${ }^{(16,17,27)}$ wishes to halve the prevalence of childhood obesity by 2025 .

England wants to reduce the prevalence in children to the level in 2000 by the year $2020^{(28)}$. Although the prevalence data are not stated in the policy document, the target corresponds to a modest reduction which will leave the prevalence at $27 \%$. The previous target set in 2004 was to halt the rise in prevalence by $2010^{(29)}$. England did not set a target for adults in either the $2008^{(28)}$ or $2004^{(29)}$ policies. This is in contrast to the 1992 English public health policy, which aimed to reduce the prevalence of obesity among adults from $8 \%$ to $6 \%$ in men and from $12 \%$ to $8 \%$ in women by $2005^{(30)}$. The prevalence of obesity in England in 2006 was $25 \%$ among men and $25 \%$ among women ${ }^{(31)}$.

\section{Targets for nutrition and physical activity}

Nutritional targets were identified for nine of the twelve countries studied: Japan ${ }^{(19)}$, New Zealand ${ }^{(32)}$, England $^{(33)}$, Northern Ireland ${ }^{(34)}$, Scotland ${ }^{(35,36)}$, Australia ${ }^{(37)}$, Denmark $^{(24)}$, the USA ${ }^{(14)}$ and Sweden ${ }^{(26)}$ (Table 2). All nine countries set a target for the consumption of fruit and vegetables and most do so for the proportion of energy from fat. There is some variation in the baseline levels and in the intended improvements, particularly in total energy from fat and sugar. It is notable that there are no targets for reduction of total energy consumption. There is considerable variation in the number of numerical targets set: Scotland ${ }^{(35)}$ and Northern Ireland ${ }^{(34)}$ set targets on all the topics most relevant to obesity, whereas 
Table 1 Targets for tackling obesity from a review of policy documents published to January 2008 by twelve developed countries

\begin{tabular}{|c|c|c|c|c|}
\hline & \multicolumn{2}{|c|}{ Baseline level } & \multicolumn{2}{|c|}{ Target level } \\
\hline & Prevalence (\%) & Date & Prevalence (\%) & Date \\
\hline \multicolumn{5}{|l|}{ USA $^{(14)}$} \\
\hline Adults at healthy weight & 42 & 1988-1994 & 60 & 2010 \\
\hline Obese adults & 23 & 1988-1994 & 15 & 2010 \\
\hline Overweight or obese children and adolescents & 11 & $1988-1994$ & 5 & 2010 \\
\hline $\operatorname{Japan}^{(19)}$ & & & & \\
\hline Obese men (20-69 years) & $24 \cdot 3$ & 1997 & $\leq 15$ & 2010 \\
\hline Obese women (40-69 years) & $25 \cdot 2$ & 1997 & $\leq 20$ & 2010 \\
\hline Obese schoolchildren & $10 \cdot 7$ & 1997 & $\leq 7$ & 2010 \\
\hline \multicolumn{5}{|l|}{ Australia $^{(22)}$} \\
\hline Children (0-18 years) & - & - & halt then reverse & 2008 \\
\hline \multicolumn{5}{|l|}{ New Zealand ${ }^{(20)}$} \\
\hline Adult males & 15 & 1997 & reduce & not stated \\
\hline Adult females & 19 & 1997 & reduce & not stated \\
\hline \multicolumn{5}{|l|}{ Northern Ireland $(16,17,27)$} \\
\hline Obese men ${ }^{(16)}$ & 17 & 1997 & $<17$ & 2010 \\
\hline Obese women ${ }^{(16)}$ & 20 & 1997 & $<20$ & 2010 \\
\hline Obese children (6 years) ${ }^{(17,27)}$ & $8 \cdot 5$ & 2001 & $\begin{array}{l}8 \cdot 5 \\
4 \cdot 2\end{array}$ & $\begin{array}{l}2010 \\
2025\end{array}$ \\
\hline Obese children (15 years) $)^{(17,27)}$ & 15 & 2001 & $\begin{array}{c}15 \\
7 \cdot 5\end{array}$ & $\begin{array}{l}2010 \\
2025\end{array}$ \\
\hline \multicolumn{5}{|l|}{ England ${ }^{(28)}$} \\
\hline $\begin{array}{l}\text { Overweight and obese children* (age not defined) } \\
\text { Denmark }^{(15)}\end{array}$ & $29 \cdot 5$ & 2006 & $26 \cdot 8$ & 2020 \\
\hline Adults ( $>16$ years) & $9 \cdot 5$ & 2000 & $9 \cdot 5$ & 2010 \\
\hline \multicolumn{5}{|l|}{ Sweden ${ }^{(26)}$} \\
\hline Men & 11 & - & prevent weight gain & - \\
\hline Women & 9 & - & & \\
\hline Children & - & - & promote normal weight & - \\
\hline
\end{tabular}

*The 2008 English policy does not specify the prevalence rates, but states the aim of reducing the prevalence to the 2000 level. The prevalence data have been taken from the Health Survey for England published in $2008^{(31)}$.

Australia ${ }^{(37)}$ sets only one target, for fruit and vegetable consumption. The targets for fruit and vegetables and for grains and cereals are difficult to compare because they are cast in different ways. Sweden points out that from a public health perspective the most significant changes in diet would include doubling the consumption of fruit and vegetables, halving the consumption of confectionery and doubling the intake of bread ${ }^{(26)}$. In addition to the information in the table, Sweden makes the commitment to decrease consumption of energy-dense food and increase consumption of keyhole-labelled foods (low-fat and/or high-fibre processed foods).

The most common target for physical activity is that a greater proportion of adults should take $30 \mathrm{~min}$ of moderate activity on most days of the week. For children the period of activity is usually $1 \mathrm{~h}$ on most days. There is some variation between countries on how often the activity should be taken and the proportion of the population who should take it. England's target is that $70 \%$ of adults should engage in moderate activity on five days of the week by $2020^{(38)}$. New Zealand aims for $75 \%$ of adults to be moderately active for at least $30 \mathrm{~min}$ on most, if not all days of the week by $2010^{(39)}$. Scotland's target is that $50 \%$ of adults over 16 years will be physically active for $30 \mathrm{~min}$ on most days and $80 \%$ of children should accumulate an hour of physical activity on most days by $2022^{(40)}$. This will require an annual increase of
$1 \%$ in the proportion being active. Sweden ${ }^{(26)}$ wishes to increase the proportion of adults who are active for at least $3.5 \mathrm{~h} /$ week, whereas for children the aim is for at least $7 \mathrm{~h} /$ week. The USA has the greatest number of targets, all of which specify the amount of improvement to be achieved by 2010. For example, it sets a target to increase both regular moderate physical activity for adults (from $15 \%$ to $30 \%$ ) and adolescents (from $27 \%$ to $35 \%)$. It also aims to increase the numbers taking part in vigorous activity as well as improving strength and endurance and flexibility. Japan wants to increase regular physical activity in men (from $29 \%$ to $39 \%$ ) and women (from $25 \%$ to $35 \%$ ) by $2010^{(19)}$. In 1996 Northern Ireland ${ }^{(16)}$ set a target of increasing the frequency of regular activity among men (from 30\% to 35\%) and women (from $20 \%$ to $25 \%$ ) by 2002 . No new targets have been set, although a 2001 evaluation found that the target had been met for women but not for men ${ }^{(41)}$. Denmark ${ }^{(24)}$ and Wales ${ }^{(42)}$ wish people to be more physically active but give few details of what is intended.

\section{Targets on knowledge and behaviour}

An important finding was the range of ambitious knowledge and behaviour targets on nutrition and physical activity set mainly by Japan, but also by the USA. Japan's nutritional targets cover knowledge of optimal body weight, appropriate meal size as well as the importance of 
Table 2 Targets for foodstuffs and nutrients most relevant to obesity from a review of policy documents published to January 2008 by twelve developed countries

\begin{tabular}{|c|c|c|c|c|}
\hline Foodstuff/nutrient & Baseline & Target & $\%$ of population & Country \\
\hline$\%$ total energy from fat & $\begin{array}{l}27 \% \\
33 \% \\
35 \% \\
35 \% \\
40 \% \\
40 \% \\
-\end{array}$ & $\begin{array}{l}<25 \% \\
30 \% \\
33 \% \\
35 \% \\
35 \% \\
35 \% \\
30 \%\end{array}$ & $\begin{array}{l}- \\
- \\
- \\
- \\
- \\
-\end{array}$ & $\begin{array}{l}\text { Japan }^{(19)} \\
\text { USA }^{(14)} \\
\text { New Zealand } \\
\text { England }^{(32)} \\
\text { Scotland } \\
\text { Northern Ireland }^{(35,36)} \\
\text { Denmark }^{(24)}\end{array}$ \\
\hline$\%$ energy from saturated fat & $\begin{array}{l}- \\
- \\
13 \cdot 3 \% \\
16 \cdot 6 \% \\
- \\
17 \cdot 5 \%\end{array}$ & $\begin{array}{l}<12 \% \\
<10 \% \\
11 \% \\
11 \% \\
10 \% \\
10 \%\end{array}$ & $\begin{array}{l}- \\
- \\
- \\
- \\
- \\
-\end{array}$ & $\begin{array}{l}\text { New Zealand }{ }^{(32)} \\
\text { USA }^{(14)} \\
\text { England }^{(33)} \\
\text { Scotland }^{(35,36)} \\
\text { Denmark }^{(24)} \\
\text { Northern Ireland }^{(34)}\end{array}$ \\
\hline$\%$ energy from sugars & $\begin{array}{l}12 \cdot 7 \% \\
- \\
20 \% \\
- \\
103 \mathrm{~g}\end{array}$ & $\begin{array}{l}11 \% \\
\text { not to increase } \\
10 \% \\
\leq 15 \% \\
60 \mathrm{~g}\end{array}$ & $\begin{array}{l}\text { - } \\
\text { adults } \\
\text { children } \\
- \\
\text { on average }\end{array}$ & $\begin{array}{l}\text { England }^{(33)} \\
\text { Scotland }^{(35,36)} \\
\text { Scotland }^{(35,36)} \\
\text { New Zealand } \\
\text { Northern Ireland } \\
\text { Nel }^{(34)}\end{array}$ \\
\hline $\begin{array}{l}\text { Daily bread and cereals } \\
\text { Bread } \\
\text { Grain products } \\
\text { Energy from complex carbohydrates } \\
\text { Complex carbohydrates } \\
\text { Potatoes and cereals } \\
\text { Confectionery }\end{array}$ & $\begin{array}{l}- \\
106 \mathrm{~g} \\
- \\
43 \% \\
124 \mathrm{~g} \\
- \\
-\end{array}$ & $\begin{array}{l}\geq 6 \text { servings } \\
154 \mathrm{~g} \\
\geq 6 \text { servings } \\
50 \% \\
155 \mathrm{~g} \\
\text { increase } \\
\text { reduce }\end{array}$ & $\begin{array}{l}75 \% \\
\text { on average } \\
50 \% \\
- \\
- \\
- \\
-\end{array}$ & $\begin{array}{l}\text { New Zealand } \\
\text { Scotland } \\
\text { USA }^{(35), 36)} \\
\text { Northern Ireland }^{(34)} \\
\text { Scotland } \\
\text { Denmark }^{(35,36)} \\
\text { Sweden }^{(26)}\end{array}$ \\
\hline Daily fruit and vegetable portions & $\begin{array}{l}4-5 \\
2 \cdot 8 \\
- \\
- \\
- \\
- \\
- \\
200 \mathrm{~g} \\
292 \mathrm{~g} \text { veg } \\
-\end{array}$ & $\begin{array}{l}7 \\
5 \\
5 \\
5 \\
600 \mathrm{~g} \\
2 \text { fruit } \\
3 \mathrm{veg} \\
>400 \mathrm{~g} \\
350 \mathrm{~g} \text { veg } \\
\text { increase consumption }\end{array}$ & $\begin{array}{l}100 \% \\
- \\
100 \% \\
75 \% \\
\text { on average } \\
75 \% \\
50 \% \\
\text { on average } \\
\text { on average } \\
-\end{array}$ & $\begin{array}{l}\text { Australia( }^{(37)} \\
\text { England }^{(33)} \\
\text { Northern Ireland }^{(34)} \\
\text { New Zealand } \\
\text { Denmarkk } \\
\text { USA }^{(14)} \\
\text { USA }^{(14)} \\
\text { Scotland( } \\
\text { Japan }^{(35)} \\
\text { Sweden }^{(26)}\end{array}$ \\
\hline
\end{tabular}

dietary behaviours such as not skipping breakfast and eating meals slowly and with friends ${ }^{(19)}$. For example, Japan wants to increase the number of people who know their optimal weight to $90 \%$ by 2010 from a baseline of $62 \%$ of men and $80 \%$ of women in 1998. It also aims to reduce the number of people who skip breakfast to $15 \%$ of adults and to zero in children by 2010 and to increase the number of people who read nutritional labels. Japan is currently developing targets for changes in the environment that will facilitate changes in diet. Topics to be covered are the provision of healthy meals in restaurants, increased provision of information and the involvement of voluntary groups in activities related to health and nutrition in the community and workplace.

Japan's physical activity targets for adults are to increase awareness about the importance of activity, to encourage vigorous exercise and also to increase walking ${ }^{(19)}$. Targets for walking are to increase the number of steps taken by 1000 steps/d for adults, the equivalent of a 10 min walk. It also wants to increase awareness of the benefits of activity and of intentional participation in activity for health reasons. Japan sets separate targets for older people. It wants them to increase walking by 1300 steps/d. It also aims to increase the number of older people who take a positive attitude towards going outside alone and who like going shopping, as well as increasing their participation in social activity.

The USA ${ }^{(14)}$ takes a different approach and specifies targets for nutrition and education at specific settings: schools, worksites and primary care. Thus it wants to increase the percentage of children and adolescents whose meals and snacks at school contribute to good dietary quality. It also wants to increase the number of worksites that offer nutrition or weight management classes or counselling. The USA also aims to increase physical activity within schools, both during and outside school hours. Importantly, it also sets a target to ensure that at least $50 \%$ of time designated to physical activity in class is spent being physically active. The USA is alone in setting a target on television watching by children: to increase the number of children who watch television for less than $2 \mathrm{~h}$ on a school day to $75 \%$ by 2010 from a 
baseline of $57 \%$ in 1999 . The targets for increasing access to physical activity include: making school facilities available outside school hours, increasing physical activity and fitness programmes in the workplace, and increasing the proportion of trips made by cycling and walking.

\section{Discussion}

The present study has found that only two of the twelve countries studied set targets for a substantial reduction in the prevalence of obesity for adults and children. Two other countries specified decreases for children only: one a substantial decrease and one a modest decrease. Four countries wanted either to halt the rise in prevalence or to reverse the trend (note that the Australian 1997 target to reverse the increase in obesity among adults was rescinded 9 years later and a new target has not yet been set $\left.{ }^{(23)}\right)$. For four other countries no targets on obesity were stated. Two of the countries studied had set ambitious targets on obesity in the early 1990s, but set much more modest targets in subsequent policy documents.

The role of targets is to provide focus and direction for policy $^{(11,43)}$, forming an essential step in improving health ${ }^{(10)}$. Given the current levels and upward trend in the prevalence of obesity, countries might be expected to commit to tackling this problem by setting ambitious targets for obesity. It is clear that many are not doing so, but instead are taking a cautious approach to the setting of obesity targets. These countries are aware of the harms arising from obesity, as many carefully review in their policy documents the morbidity, mortality and medical and financial costs ${ }^{(2)}$. Nor is there a lack of willingness to set challenging targets, as all the countries studied set overarching goals to increase life expectancy or healthy life expectancy and to reduce inequalities in health ${ }^{(44)}$.

One explanation for the reluctance to set ambitious targets could be that many countries are adopting a pragmatic approach to target setting for obesity. They may recognize that the prevalence of obesity is set to continue to rise and that tackling the problem is beset with difficulties. Certainly New Zealand, in a 1997 review of progress on targets ${ }^{(21)}$, used this argument to justify its then target on obesity. If pragmatism is the answer, this suggests that some governments are unwilling at present to take vigorous action to reduce the serious health and economic consequences of obesity.

Many targets are set for nutrition and physical activity. The nutritional targets almost always specify the amount of intended improvement and the date by which this should be achieved. However, the form in which some of the nutritional targets are cast, such as percentage of energy from fat or the number of grams of carbohydrate to be consumed, do not translate easily into changes in diet. In contrast, the recommendation to eat 5 portions of fruit and vegetables daily is easily operationalized.
It is surprising that none of the countries set targets for reductions in energy consumption. Reducing energy consumption is essential for weight loss and it is also a message which is readily understood. This would be most easily achieved by reductions in the consumption of fatty/ sugary foods which several countries (e.g. Sweden ${ }^{(26)}$, New Zealand ${ }^{(45)}$ and Denmark ${ }^{(15)}$ ) wish to achieve. It is disappointing that only Sweden ${ }^{(26)}$ sets a target for a reduction in the consumption of confectionery. Sweden is also investigating the potential for reducing consumption of confectionery by increasing taxes.

The impact the nutritional targets may have is uncertain. Several countries have had similar nutritional targets for many years ${ }^{(46-49)}$ during which time obesity rates have been rising ${ }^{(50-52)}$. This suggests that these targets may be more an expression of improvements that governments desire than a formal commitment to ensure that dietary changes occur.

There is considerable variation in the physical activity targets across the countries. Although some countries set specific targets, others express a more general desire for people to be more active. The targets currently set for adults, of $30 \mathrm{~min}$ of regular exercise per day, may have been set because this was the level at which substantial health benefits would be gained ${ }^{(53,54)}$. However, a more recent consensus statement concluded that these levels would be insufficient to prevent the transition from overweight to obesity ${ }^{(55)}$. The activity time would need to be extended to 45 to $60 \mathrm{~min} / \mathrm{d}$. Physical activity is an important issue for older people because their activity levels are low ${ }^{(56,57)}$ and the benefits of physical activity for them are well-established ${ }^{(58-60)}$. Only Japan sets targets for activity levels for older people.

Some of the targets, particularly those of Japan but also some from the USA, are of a quite different type to those set by other countries. The Japanese nutrition targets, such as knowledge of portion size or reading of nutritional labels, are attractive because they identify prerequisites to changes in dietary behaviour. Some of the US targets, such as worksites offering counselling on nutrition and weight management, focus on specific mechanisms which could lead to changes in dietary behaviour. The physical activity targets from both countries also provide examples of behavioural change prerequisites and mechanisms for changing behaviour. These targets identify a series of steps that will facilitate the achievement of the longer-term goal of reducing the level of obesity. Figure 1 illustrates how these steps can be organized in a sequence: prerequisites for change, preparatory behaviour change, lifestyle change and finally reduced level of obesity. The prerequisites for change are increased knowledge of healthy eating and physical activity, combined with beliefs about the benefits of a healthy lifestyle. A further requirement is a supportive environment in which healthy food and opportunities for physical activity are readily available. Preparatory 


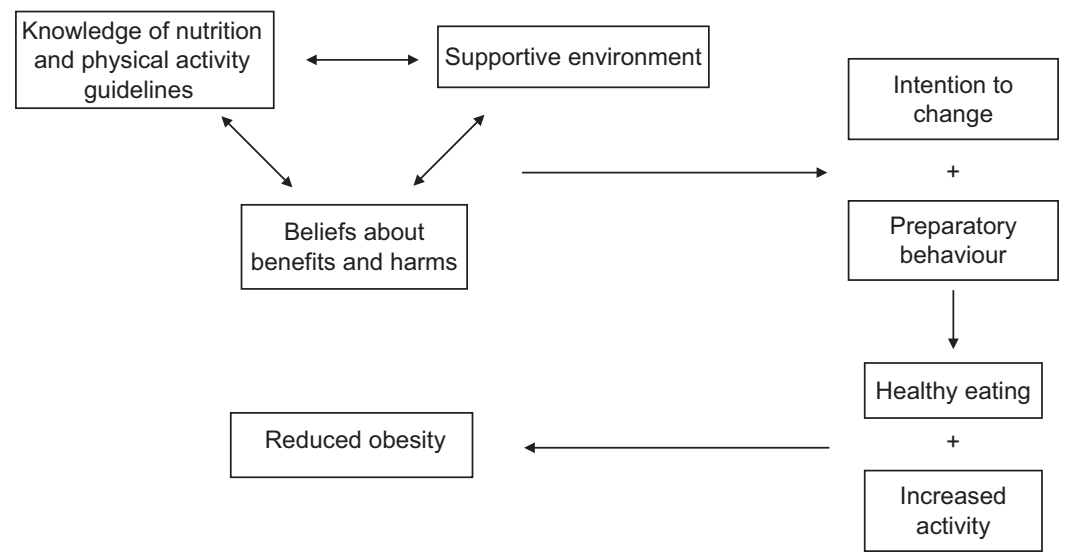

Fig. 1 Indicators of progress towards behaviour changes needed to reduce levels of obesity

behaviour change involves individuals resolving to change their lifestyles and undertaking preparatory behaviours such as reading food labels. This is followed by dietary changes which lead to reduced energy intake and increased physical activity. These will lead, in the longer term, to reduced levels of obesity.

The present study found that most countries set targets which focus on changed dietary behaviour and physical activity or reduced levels of obesity. These are near to the end of the sequence to obesity reduction shown in Fig. 1. In contrast, some of the targets from Japan and the USA cover the intermediate and early stages of the pathway. Such targets are likely to detect desirable changes more rapidly than the traditional targets, allowing early opportunities for modification to policy implementation. All countries could usefully adopt these types of targets. Such targets could be more attractive to governments than headline obesity targets. The desired changes are more readably achievable in the short term and are an important first step towards reducing the prevalence of obesity. An additional benefit of intermediate targets is that governments can assess progress to achieving them within one electoral cycle.

In summary, we have found that if targets are a proxy for government commitment, there is insufficient drive to reduce the prevalence of obesity. It may be that governments are being pragmatic, recognizing the difficulty of making major changes in nutrition and physical activity. Governments may have to balance their concerns for an efficient and productive agricultural sector and their concern for health ${ }^{(61,62)}$. It is also possible that the food industry has successfully lobbied governments ${ }^{(63)}$. Whatever the explanation, the consequence of the lack of commitment is an acceptance of the dire health sequelae of the obesity epidemic. A report from England suggests a fall in life expectancy of 9 years ${ }^{(64)}$ and one from Sweden states that the increased health-care costs of morbidity associated with obesity could not be sustained ${ }^{(26)}$. There is an urgent need for governments to reconsider targets on obesity.

\section{Acknowledgements}

There are no conflicts of interest. I.K.C., L.I. and L.E. conceived and supervised the study. L.I. and H.W. identified and retrieved the policy documents. I.K.C. and L.I. analysed the policies and led the writing. L.E. and H.W. assisted with the writing. This study was funded by NHS Health Scotland, a branch of the Scottish Executive Health Department. We are grateful to Dr L. Gruer for encouragement and support to undertake this work.

\section{References}

1. World Health Organization (1998) The world health report 1998 - Life in the 21st century: A vision for all. http://www.who.int/whr/1998/en/ (accessed February 2008).

2. Crombie IK, Irvine L, Elliott L \& Wallace H (2005) Public Health Policy to tackle obesity: An International Perspective. http://www.healthscotland.com/uploads/documents/ obesity_full_report.pdf (accessed February 2008).

3. van Herten LM \& Gunning-Schepers LJ (2000) Targets as a tool in health policy. Part I: lessons learned. Health Policy 52, 1-11.

4. US Department of Health, Education, and Welfare (1979) Healthy People. The Surgeon General's Report on Health Promotion and Disease Prevention. http://profiles.nlm. nih.gov/NN/B/B/G/K/_nnbbgk.pdf (accessed February 2008).

5. World Health Organization (1979) Formulating Strategies For Health For All By The Year 2000. Geneva: WHO.

6. World Health Organization (1993) Health for All Targets. The Health Policy for Europe. European Health for All Series no. 4. Copenhagen: WHO Regional Office for Europe.

7. Ritsatakis A, Barnes R, Dekker E, Harrington P, Kokko S \& Makara P (2000) Exploring Health Policy Development in Europe. WHO Regional Publications European Series no. 86. Copenhagen: WHO Regional Office for Europe.

8. Gunning-Schepers LJ \& van Herten LM (2000) Targets in health policy. Eur J Public Health 10, 2-6. 
9. World Health Organization (1999) Health 21. The Health For All Policy Framework for the WHO European Region. European Health for All Series no. 6. Copenhagen: WHO Regional Office for Europe.

10. Nutbeam D \& Wise M (1996) Planning for health for all: international experience in setting health goals and targets. Health Promot Int 11, 219-226.

11. van Herten LM \& Gunning-Schepers LJ (2000) Targets as a tool in health policy. Part II: guidelines for application. Health Policy 53, 13-23.

12. van de Water HPA \& van Herten LM (1998) Health Policies on Target? Review of Health Target and Priority Setting in 18 European Countries. The Hague: TNO Prevention and Health.

13. van Herten LM \& van de Water HPA (2000) Health policies on target? Review on health target setting in 18 European countries. Eur J Public Health 10, 11-16.

14. US Department of Health and Human Services (2000) Healthy People 2010. http://www.healthypeople.gov/ Publications/ (accessed February 2008).

15. National Board of Health (2003) National Action Plan Against Obesity. Recommendations and perspectives. Short version. http://www.sst.dk/publ/publ2003/National_ action_plan.pdf (accessed February 2008).

16. Ministry for Health, Social Services and Public Safety (2002) Investing for Health. http://www.dhsspsni.gov.uk/show publications?txtid $=10415$ (accessed February 2008).

17. Department of Health, Social Services and Public Safety (2004) A Healthier Future. A twenty year vision for health and wellbeing in Northern Ireland 2005-2025. http://www.dhsspsni.gov.uk/show_publications?txtid=7282 (accessed February 2008).

18. US Department of Health and Human Services (1990) Healthy People 2000. Parts 1 \& 2. Washington, DC: US Government Printing Office.

19. Ministry of Health and Welfare (2000) National Health Promotion in the 21st Century (Health Japan 21). Tokyo: Japanese Government.

20. Ministry of Health (2000) The New Zealand Health Strategy. http://www.moh.govt.nz/moh.nsf/0/FB62475D5D911E88CC 256D42007BD67E/\$File/newzealandhealthstrategy.pdf (accessed February 2008).

21. Ministry of Health (1997) Progress on Health Outcome Targets. The State of Public Health in New Zealand 1997. Wellington: New Zealand Government.

22. National Obesity Taskforce (2004) Healthy Weight 2008 Australia's Future: The National Action Agenda for Children and Young People and their Families. http://www.health.gov. $\mathrm{au} /$ internet/healthyactive/publishing.nsf/Content/healthy_ weight08.pdf/\$File/healthy_weight08.pdf (accessed February 2008).

23. National Health and Medical Research Council (1997) Acting on Australia's weight. A strategic plan for the prevention of obesity (rescinded 2209 2006). http://www. nhmrc.gov.au/publications/synopses/withdrawn/n21.pdf (accessed February 2008).

24. Ministry of Health (1999) The Danish Government Programme on Public Health and Health Promotion 19992008. http://www.folkesundhed.dk/media/folkesundhed_ engelsk.pdf (accessed February 2008).

25. Ministry of the Interior and Health (2000) Healthy throughout Life - the targets and strategies for public health policy of the Government of Denmark, 2002-2010. http://www.folkesundhed.dk/media/healthythroughoutlife. pdf (accessed February 2008).

26. National Food Administration, National Institute of Public Health (2005) Background material to The Action Plan for Healthy Dietary Habits and Increased Physical Activity. http://www.fhi.se/upload/2702/TheSwedishActionplan. pdf (accessed February 2008).
27. Department of Health Social Services and Public Safety (2005) Fit Futures: Focus on Food, Activity and Young People. Report to the Ministerial Group on Public Health. http://www.dhsspsni.gov.uk/ifh-fitfutures.pdf (accessed February 2008).

28. Department of Health \& Department for Children, Schools and Families (2008) Healthy Weight, Healthy Lives. A Cross Government Strategy for England. http://www.dh.gov.uk/ en/Publicationsandstatistics/Publications/PublicationsPolicy AndGuidance/DH_082378 (accessed February 2008).

29. Department of Health (2004) Choosing Health: Making healthy choices easier. http://www.dh.gov.uk/assetRoot/ 04/12/07/92/04120792.pdf (accessed February 2008).

30. Department of Health (1992) The Health of the Nation. London: HMSO.

31. The Information Centre (2008) Health Survey for England 2006 Latest Trends. http://www.ic.nhs.uk/statistics-anddata-collections/healthand-lifestyles-related-surveys/healthsurvey-for-england/health-survey-for-england-2006-latesttrends (accessed February 2008)

32. Ministry of Health (2001) DHB Toolkit. Improve Nutrition. http://www.moh.govt.nz/moh.nsf/pagesmh/5508/\$File/ nutrition-toolkit.doc (accessed February 2008).

33. Department of Health (2005) Choosing a Better Diet: a food and health action plan. http://www.dh.gov.uk/ assetRoot/04/10/57/09/04105709.pdf (accessed February 2008).

34. Health Promotion Agency (1996) Eating and Health. A food and nutrition strategy for Northern Ireland. http://www. healthpromotionagency.org.uk/Resources/nutrition/pdfs/ Nutritionstrategy.pdf (accessed February 2008).

35. The Scottish Office (1996) Eating for Health - A diet action plan for Scotland. http://www.scotland.gov.uk/library/ documents/diet-00.htm (accessed February 2008).

36. Scottish Executive (2004) Eating for Health - Meeting the challenge. http://www.scotland.gov.uk/library5/health/ efhmtc.pdf (accessed February 2008).

37. The National Public Health Partnership (2001) Eat Well Australia. A Strategic Framework for Public Health Nutrition 2000-2010. http://www.nphp.gov.au/publications/signal/ eatwell1.pdf (accessed February 2008).

38. Department of Culture Media and Sport \& The Strategy Unit (2002). Game Plan: a strategy for delivering Government's sport and physical activity objectives. http://www.isrm. co.uk/reference/documents/gameplanpart1_000.pdf (accessed February 2008).

39. Ministry of Health (2003) DHB Toolkit. Physical Activity. http://www.moh.govt.nz/moh.nsf/pagesmh/5535/\$File/ physical-activity-toolkit.pdf (accessed February 2008).

40. Physical Activity Task Force (2003) Let's Make Scotland More Active. A strategy for physical activity. http:// www.scotland.gov.uk/library5/culture/lmsa.pdf (accessed February 2008).

41. Northern Ireland Statistics and Research Agency (2002) Northern Ireland Health and Social Wellbeing Survey 2001. Physical activity results - Activity level tables. http:// www.nisra.gov.uk/whatsnew/wellbeing/physical_activity/ index.html (accessed February 2008).

42. Ministry for Health and Social Services (2003) Healthy and active lifestyles in Wales: A framework for action. http://www.wales.nhs.uk/documents/healthactlifewales-e. pdf (accessed February 2008).

43. van Herten L \& Gunning-Schepers L (2002) Historical perspectives on European health and policy. In Health Targets in Europe, pp. 18-33 [M Marinker, editor]. London: BMJ Books.

44. Crombie IK, Irvine L, Elliott L \& Wallace H (2005) Closing the Health Inequalities Gap: An International Perspective. http://www.euro.who.int/Document/E87934.pdf (accessed February 2008). 
45. Ministry of Health (2003) Healthy Eating - Healthy Action. A strategic framework. http://www.moh.govt.nz/moh.nsf/0/ 6088A42CFAA9AC6FCC256CE0000DAE66/\$File/hehastrategic framework.pdf (accessed February 2008).

46. Gifford KD (2002) Dietary fats, eating guides, and public policy: history, critique, and recommendations. Am J Med 113, Suppl. 9B, 89S-106S

47. Bush M \& Kirkpatrick S (2003) Setting dietary guidance: the Canadian experience. J Am Diet Assoc 103, Suppl. 2, S22-S27.

48. Stockley L (2001) Toward public health nutrition strategies in the European Union to implement food based dietary guidelines and to enhance healthier lifestyles. Public Health Nutr 4, 307-324.

49. Curran MA (2002) Nutrition labelling: perspectives of a bi-national agency for Australia and New Zealand. Asia Pac J Clin Nutr 11, S72-S76.

50. Kettel Khan L \& Bowman BA (1999) Obesity: a major global public health problem. Annu Rev Nutr 19, xiii-xvii.

51. Rossner S (2002) Obesity: the disease of the twentyfirst century. Int J Obes Relat Metab Disord 26, Suppl. 4, S2-S4.

52. Lobstein T \& Frelut ML (203) Prevalence of overweight among children in Europe. Obes Rev 4, 195-200.

53. Pate R, Pratt M, Blair S et al. (1995) Physical activity and public health. A recommendation from the Centers for Disease Control and Prevention and the American College of Sports Medicine. JAMA 273, 402-407.

54. US Department of Health and Human Services (1996) Physical Activity and Health. A Report of the Surgeon General. Executive Summary. http://www.cdc.gov/nccdphp/ sgr/pdf/execsumm.pdf (accessed February 2008).
55. Saris WH, Blair SN, van Baak MA et al. (2003) How much physical activity is enough to prevent unhealthy weight gain? Outcome of the IASO 1st Stock Conference and consensus statement. Obes Rev 4, 101-114.

56. Crombie IK, Irvine L, Williams B, McGinnis AR, Slane PW, Alder EM \& McMurdo ME (2004) Why older people do not participate in leisure time physical activity: a survey of activity levels, beliefs and deterrents. Age Ageing 33, 287-292.

57. Macera CA, Ham SA, Yore MM, Jones DA, Ainsworth BE, Kimsey CD \& Kohl HW 3rd (2001) Prevalence of physical activity in the United States: Behavioral Risk Factor Surveillance System, 2001. Prev Chronic Dis 2, A17.

58. American College of Sports Medicine (1998) American College of Sports Medicine Position Stand. Exercise and physical activity for older adults. Med Sci Sports Exerc 30, 992-1008.

59. DiPietro L (2001) Physical activity in aging: changes in patterns and their relationship to health and function. J Gerontol A Biol Sci Med Sci 56, Spec. No. 2, 13-22.

60. Mazzeo RS \& Tanaka H (2001) Exercise prescription for the elderly: current recommendations. Sports Med 31, 809-818.

61. Lobstein T (2002) Food policies: a threat to health? Proc Nutr Soc 61, 579-585.

62. Tillotson JE (2004) America's obesity: conflicting public policies, industrial economic development, and unintended human consequences. Annu Rev Nutr 24, 617-643.

63. Nestle M (2002) Food Politics. Berkeley, CA: University of California Press.

64. House of Commons Health Committee (2004) Obesity. Third Report of Session 2003-04, vol. 1. http://www. parliament.thestationery-office.co.uk/pa/cm200304/cmselect/ cmhealth/23/23.pdf (accessed February 2008). 